
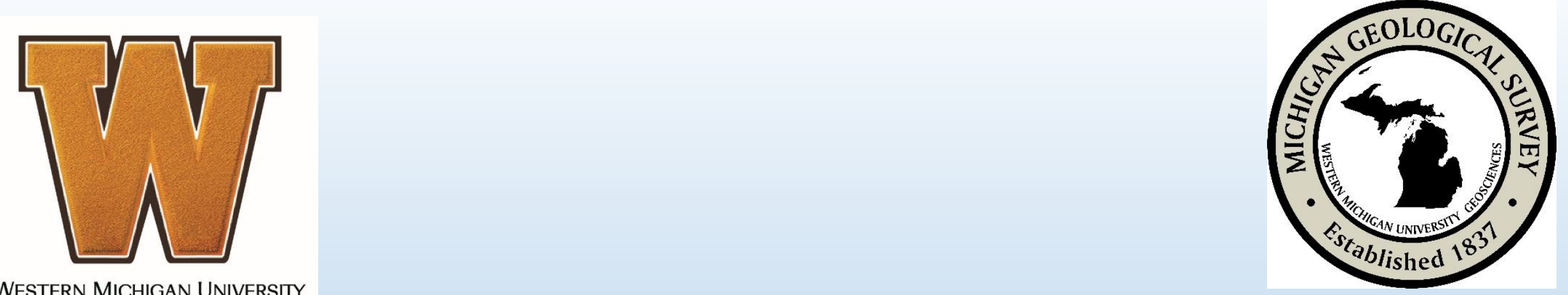

\title{
Western Michigan University's CoreKids Program: K-12 Outreach using Student Educators
}

Peter Voice ${ }^{1,2}$, S. Grammer ${ }^{3}$, G. M. Grammer ${ }^{4}$, W.B. Harrison III ${ }^{1,2}$, H. Petcovic ${ }^{1}$, and J. Yellich ${ }^{1,5}$

${ }^{1}$ Department of Geological and Environmental Sciences, Western Michigan University

${ }^{2}$ Michigan Geological Repository for Research and Education, Western Michigan University

${ }^{3}$ Biotechwrite: Biomedical and Science Communications

${ }^{4}$ Boone Pickens School of Geology, Oklahoma State University

${ }^{5}$ Michigan Geological Survey, Western Michigan University

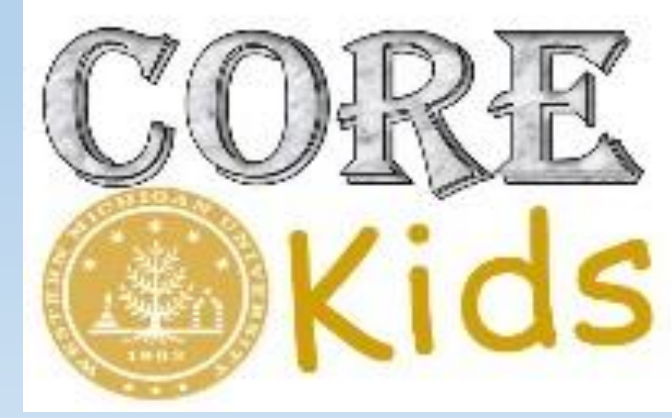




\section{WMU Geological and Environmental Sciences Outreach Platform}

- On-campus - the Lloyd Schmaltz Geology and Mineral Museum, Rock Garden, and Dinosaur Park - tours

- Michigan Geological Repository for Research and Education - off-campus home of the Michigan Geological Survey - tours, professional training (teachers workshops and professional geologists workshops)

- CoreKids Program - external outreach activities - school visits, booths at allied partner events (other Museums, mineral shows, etc.)

- CoreKids Website - resources, links to high quality websites for various Geo-topics, Program Annual Reports and News (https://wmich.edu/corekids)

- Combined impact - on order of 20,000+ people per year 


\section{WMU Geological and Environmental Sciences Outreach Platform}

-Facilities and activities

- Rood Hall - main campus - the Lloyd Schmaltz Geology and Mineral Museum, Rock Garden, and Dinosaur Park - tours

- Michigan Geological Repository for Research and Education (MGRRE) - near campus - tours, professional training, workshops for teachers and professional geologists - hosts the Michigan Geological Survey (MGS)

- CoreKids Program - external outreach activities - school visits, exhibits at partner events (other Museums, mineral shows, etc.)

- CoreKids Website - resources and links to websites with great content for Geo-topics and classroom planning, and Program Annual Reports and News (https://wmich.edu/corekids) 


\section{MGRRE, MGS and CoreKids}

- WMU - home to the Michigan Geological Survey (MGS), and the Michigan Geological Repository for Research and Education (MGRRE)

- CoreKids - outreach arm of MGRRE since 2007 and for the MGS since 2012

- 20-50 events per year, $10,000-20,000$ contacts per year

- Mix of hands-on activities and presentations from themed modules

- Grant-funded

- Most events - focused towards $4^{\text {th }}, 6^{\text {th }}$, and $8^{\text {th }}$ grades - due to prior Earth Science Teaching Standards

- Allied Partner Events - Gem and Mineral Shows, Career Exploration Fairs, Science Fairs 
The Lloyd Schmaltz Geology Museum
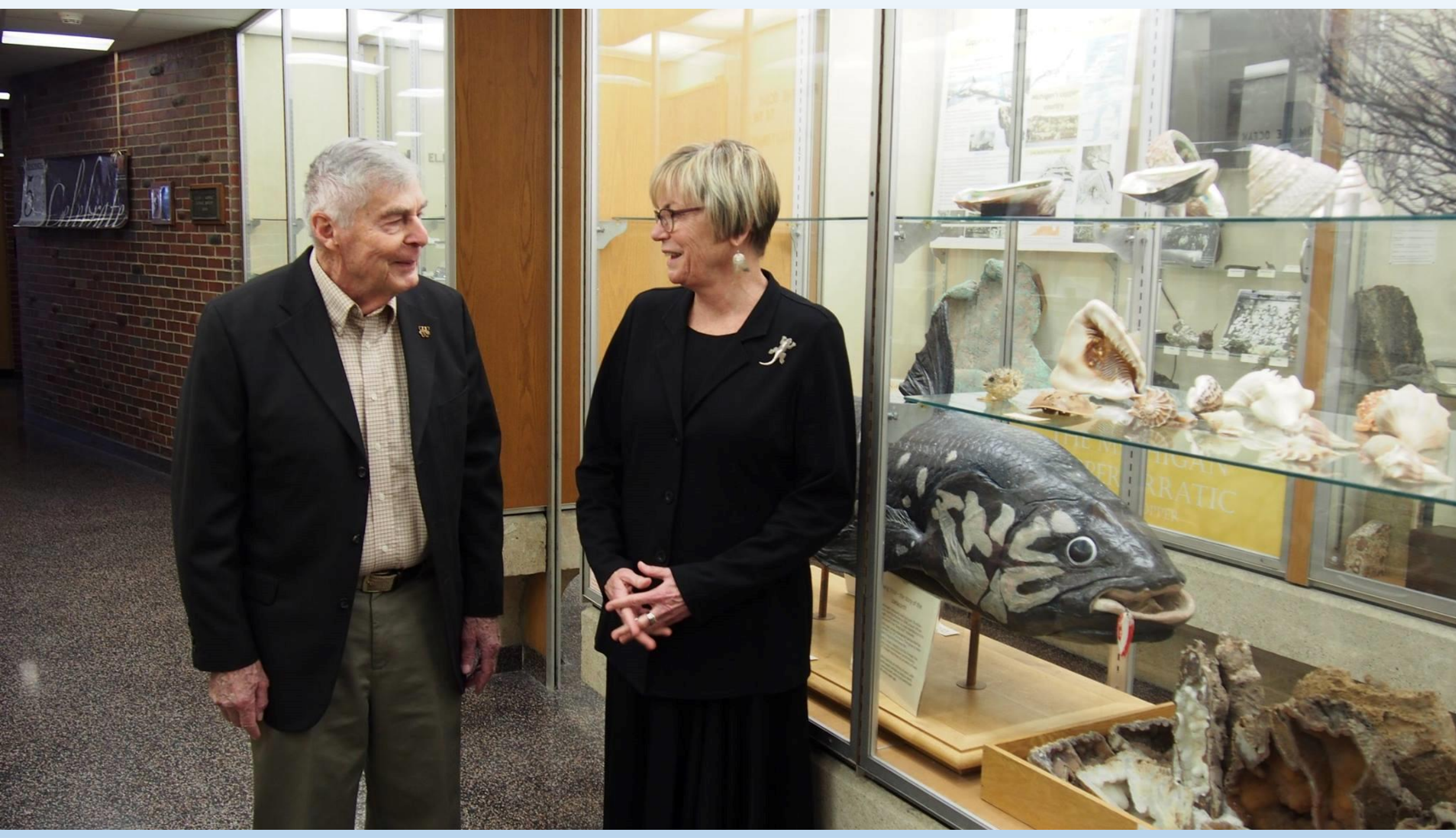

Lloyd Schmaltz (Dept. Chair - 1959-1988) and Dr. Julie Stein (Director, Washington Natural History Museum and WMU Graduate) 


\section{Augmented Reality}

\section{Sandbox}

- Portable - take to classrooms, external events

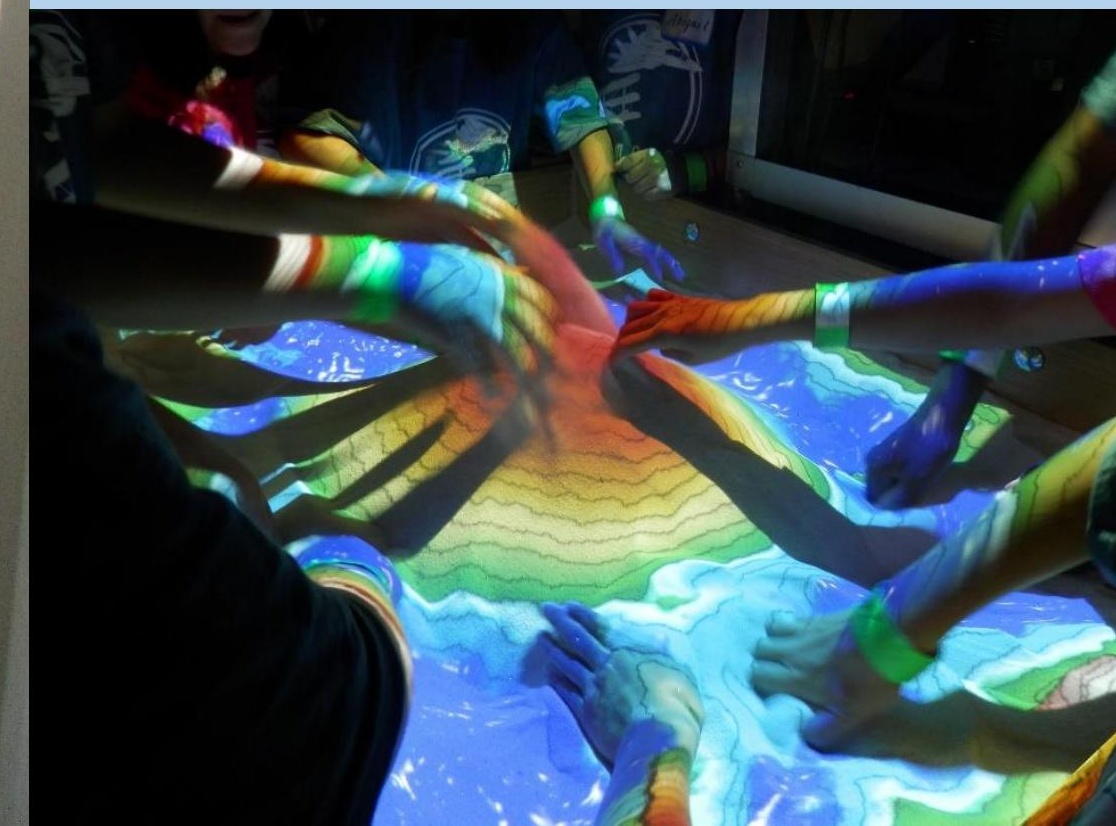




\begin{tabular}{|c|c|c|c|}
\hline Module & $\begin{array}{l}\text { Recommended } \\
\text { Grade Level }\end{array}$ & $\begin{array}{l}\text { Michigan } \\
\text { Department } \\
\text { of Education } \\
\text { Standards }\end{array}$ & Description \\
\hline $\begin{array}{l}\text { Michigan Geologic } \\
\text { History }\end{array}$ & $2-12$ & $\begin{array}{l}\text { E.ES.03.41, } \\
\text { E.ES.03.32, } \\
\text { E.ST.04.31, } \\
\text { E.SE.06.12, } \\
\text { E.ST.06.42, } \\
\text { E4.p3A }\end{array}$ & $\begin{array}{l}\text { Discussion of Michigan's Geologic } \\
\text { resources in their historical geology } \\
\text { context. Emphasis on resources such as } \\
\text { Oil and Gas, and Groundwater }\end{array}$ \\
\hline Hydrogeology & $7-12$ & $\begin{array}{l}\text { E.ES.07.81, } \\
\text { E4.1A, E4.1C }\end{array}$ & $\begin{array}{l}\text { Discussion of infiltration rates, porosity } \\
\text { and permeability. }\end{array}$ \\
\hline $\begin{array}{l}\text { Natural Hazards: } \\
\text { Earthquakes }\end{array}$ & $6-12$ & $\begin{array}{l}\text { E.SE.06.51, } \\
\text { E.SE.06.52, } \\
\text { E.SE.06.53, } \\
\text { E3.4A, E3.4C, } \\
\text { E3.4f }\end{array}$ & $\begin{array}{l}\text { Emphasis is on vibrational energy of } \\
\text { earthquakes and its impact on structures. }\end{array}$ \\
\hline $\begin{array}{l}\text { Natural Hazards: } \\
\text { Volcanoes }\end{array}$ & $4-12$ & $\begin{array}{l}\text { E.SE.06.52, } \\
\text { E3.1d, E3.4C, } \\
\text { E3.4d, E3.4e, } \\
\text { E5.4B }\end{array}$ & $\begin{array}{l}\text { Flow rates and magma chemistry are used } \\
\text { to classify different types of volcanic } \\
\text { eruptions. Volcanoes as natural hazards } \\
\text { are explored. }\end{array}$ \\
\hline $\begin{array}{l}\text { Natural Hazards: } \\
\text { Impacts and Asteroids }\end{array}$ & $2-12$ & $\begin{array}{l}\text { E5.p1A, E5.3C, } \\
\text { E5.4B, P3.6A, } \\
\text { P3.6B }\end{array}$ & $\begin{array}{l}\text { Describes the influence of asteroids on } \\
\text { Earth's geologic history. }\end{array}$ \\
\hline $\begin{array}{l}\text { Shale Energy and } \\
\text { Hydraulic Fracturing }\end{array}$ & $7-12$ & $\begin{array}{l}\text { E.ES.03.41, } \\
\text { E.ES.03.32, } \\
\text { E2.2B, E2.4A, } \\
\text { E2.4B, E3.1C, } \\
\text { E4.1C }\end{array}$ & $\begin{array}{l}\text { Discussion of conventional vs. } \\
\text { unconventional hydrocarbon reservoirs. } \\
\text { Explains the process by which hydraulic } \\
\text { fracturing occurs. }\end{array}$ \\
\hline Michigan Fossils & $2-12$ & $\begin{array}{l}\text { E.ST.04.31, } \\
\text { E.ST.06.31, } \\
\text { E.ST.04.32, } \\
\text { E.St.06.42, } \\
\text { Ef.3D, E5.4f }\end{array}$ & $\begin{array}{l}\text { Michigan fossils are used to explore } \\
\text { Michigan's changing climate as a function } \\
\text { of plate tectonics through geologic time. } \\
\text { Fossils are used to explore basic ecological } \\
\text { principles (food webs, competition, } \\
\text { niches). }\end{array}$ \\
\hline $\begin{array}{l}\text { The Environment and } \\
\text { Climate Change }\end{array}$ & $2-12$ & $\begin{array}{l}\text { E.ES.03.52, } \\
\text { E.ES.07.41, } \\
\text { E1.2B, E1.2f, } \\
\text { E1.2g, E2.3A, } \\
\text { E2.3d, E2.4B, } \\
\text { E5.4A, E5.4e }\end{array}$ & $\begin{array}{l}\text { Module presents an overview of the } \\
\text { nature of carbon dioxide gas and the } \\
\text { greenhouse effect. The albedo effect is } \\
\text { used illustrate the impact of changes in } \\
\text { land cover and land use. }\end{array}$ \\
\hline \multicolumn{4}{|c|}{$\begin{array}{l}\text { Modules - mix of hands-on activities, presentations, } \\
\text { display samples. Keyed to grade level and State Science } \\
\text { Standards (NGSS) }\end{array}$} \\
\hline
\end{tabular}

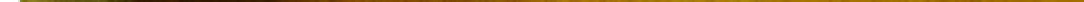




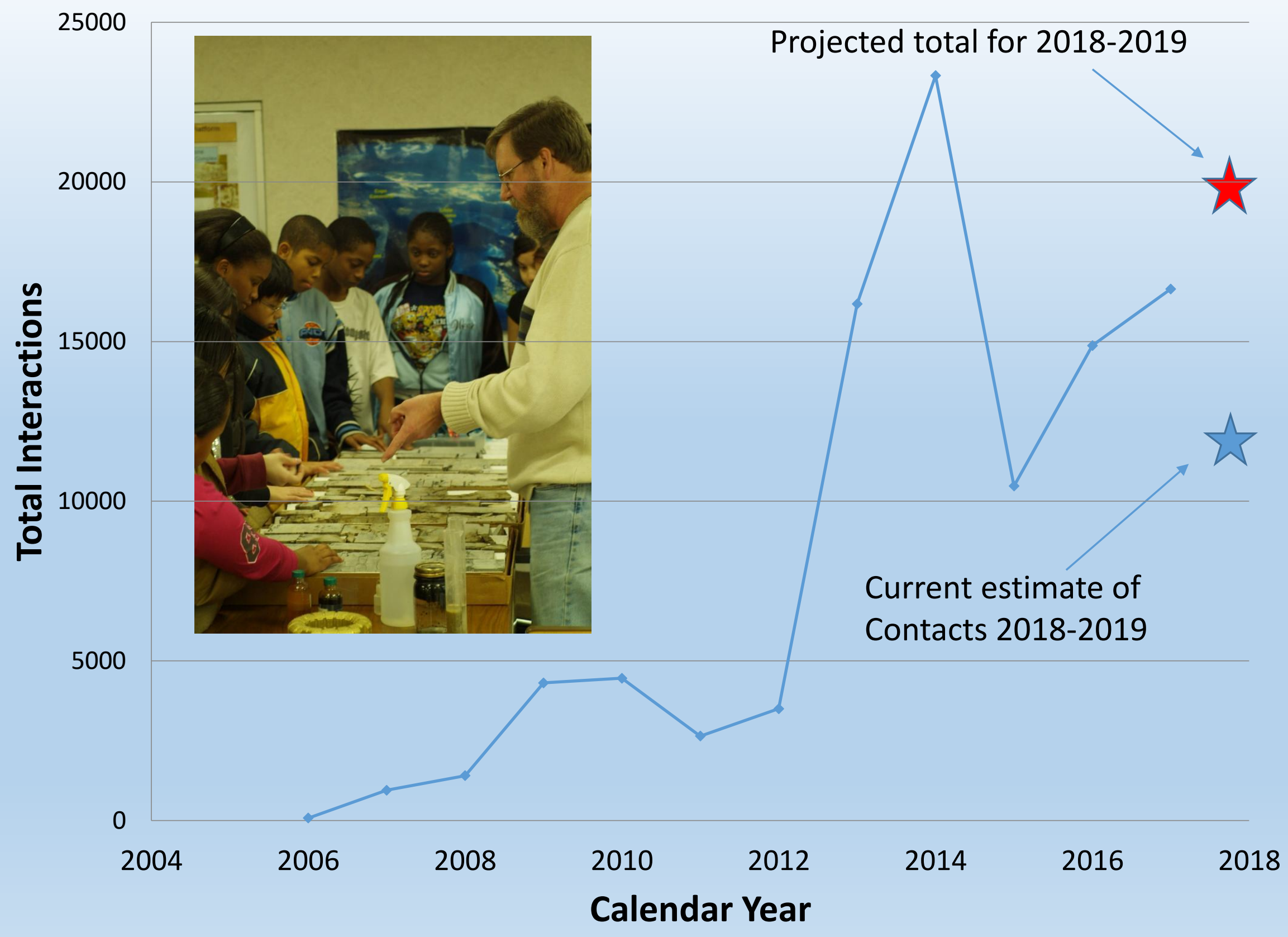




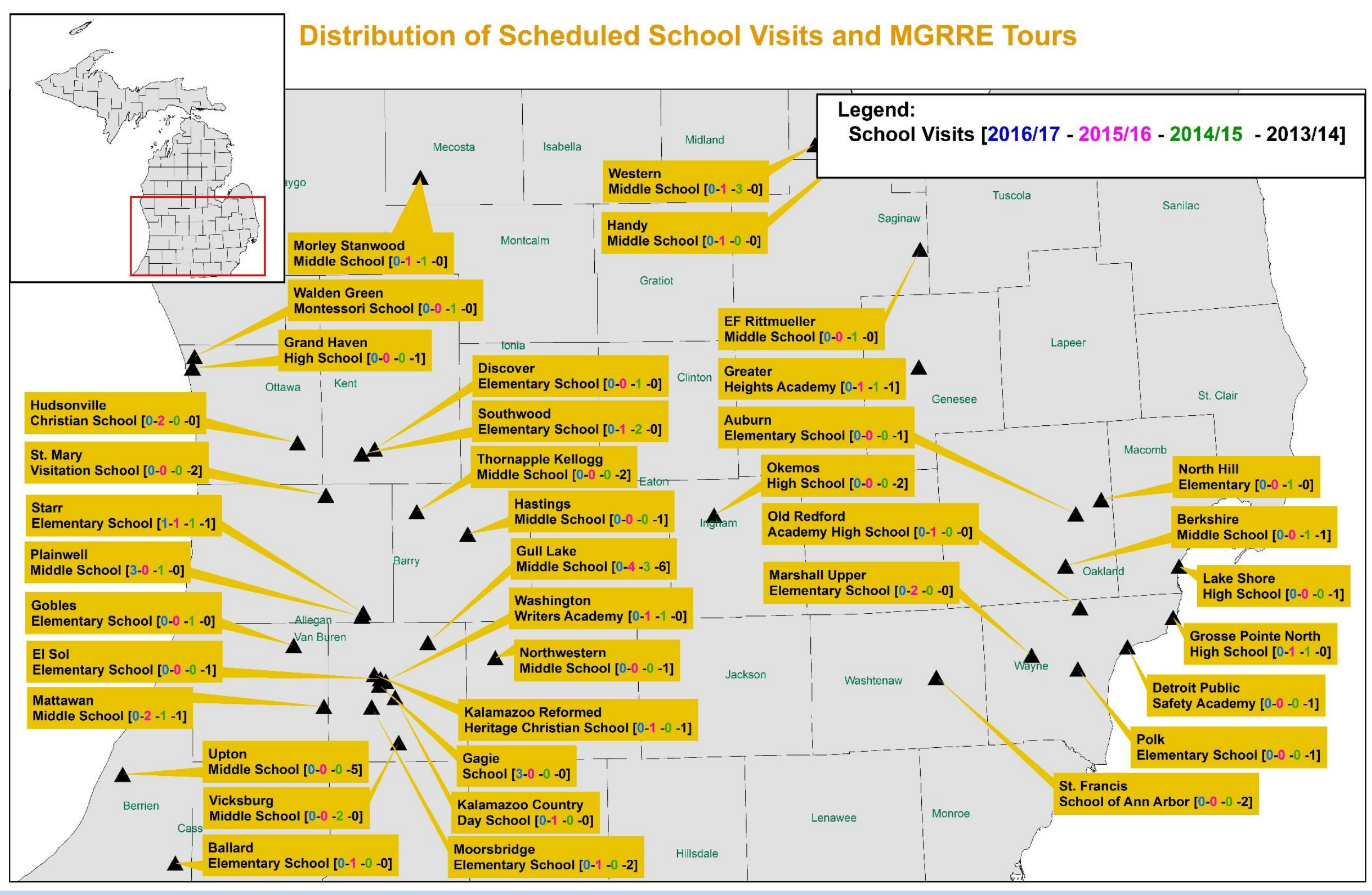

Be Selective - Even though we are the home of the Geological Survey of Michigan, we cannot be everywhere in the state. Parts of the UP are 10-12 hours drive 1-way from Kalamazoo! We limited our geographic footprint due to funds, travel liabilities, and student fatigue. 
Individual school visits are very meaningful to both teachers and students. However, the are more costly due to travel and student stipends, and they result in fewer contacts per event.

\section{5-2016 School Year}
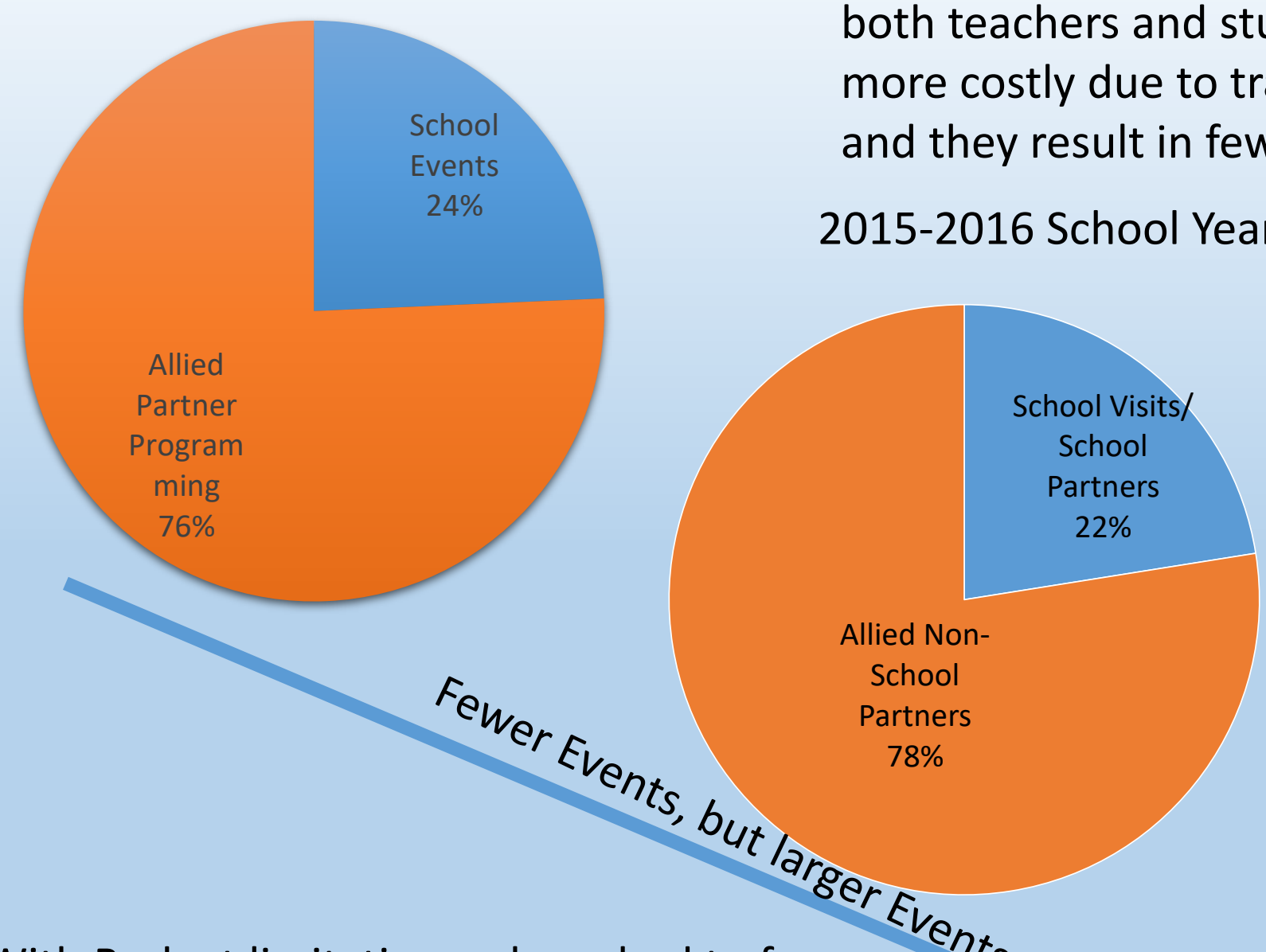

With Budget limitations - have had to focus on ${ }^{\text {nts }}$ allied partner programming for contacts

- Provide Content - booths, volunteers, activities

- Allies provide promotional materials, access to location, and networks of attendees (often lead to other events) 


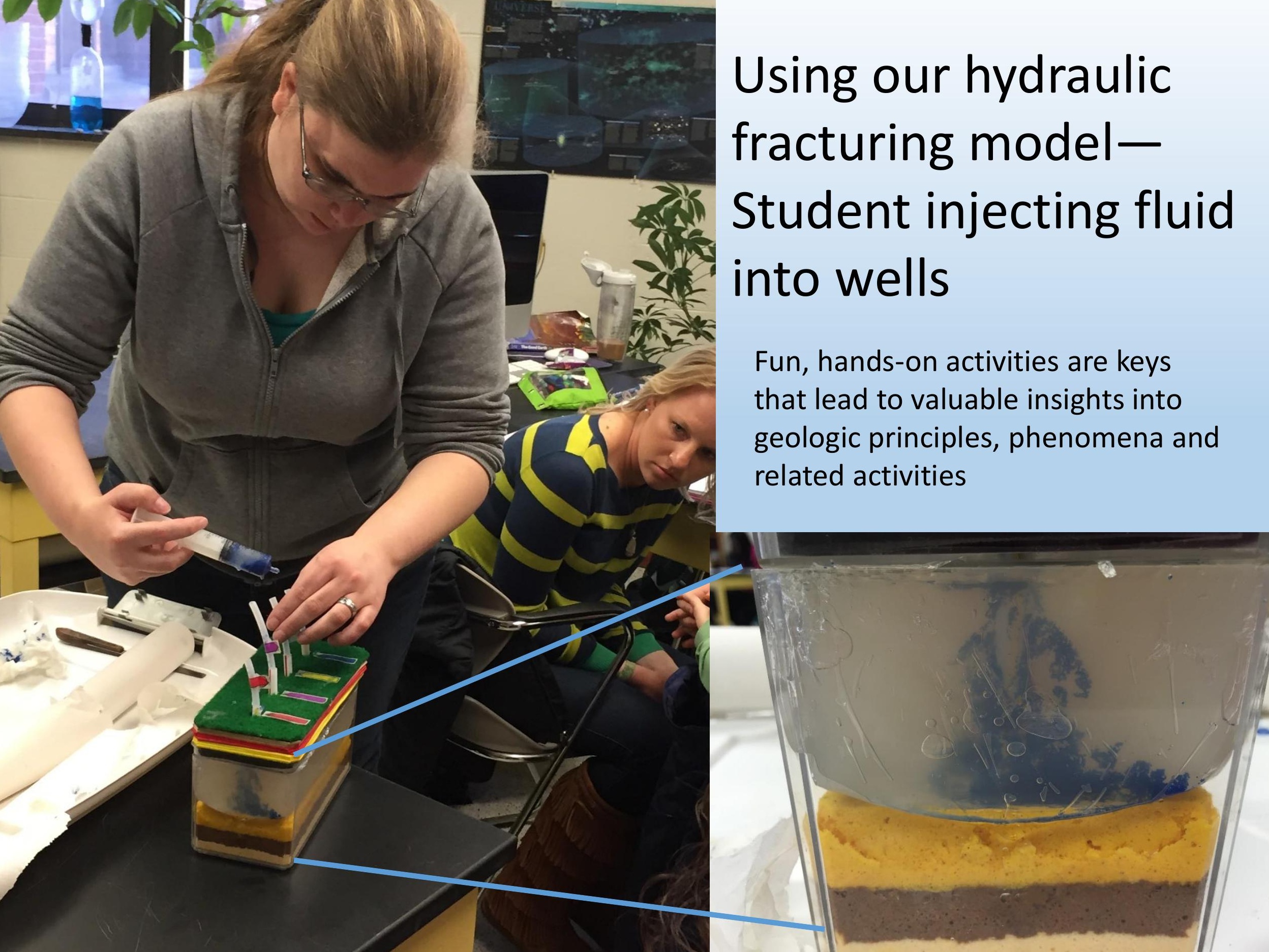


Some of Our Educators have gone on to Teaching Positions, State Regulatory Agencies, and Industry. All of them still engage in outreach at their new positions!
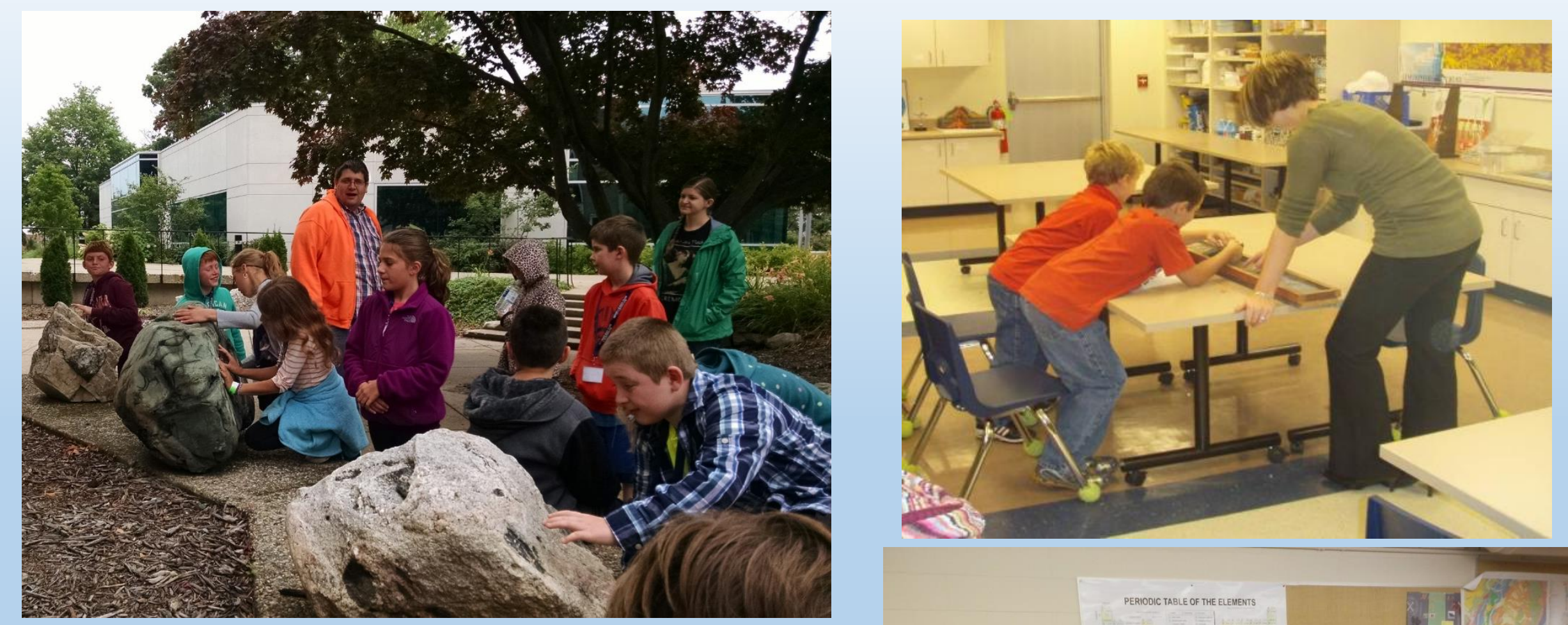

Our Student Educators gain valuable experience:

- Communicating our science

- Interacting with the public

They hone their public speaking skills

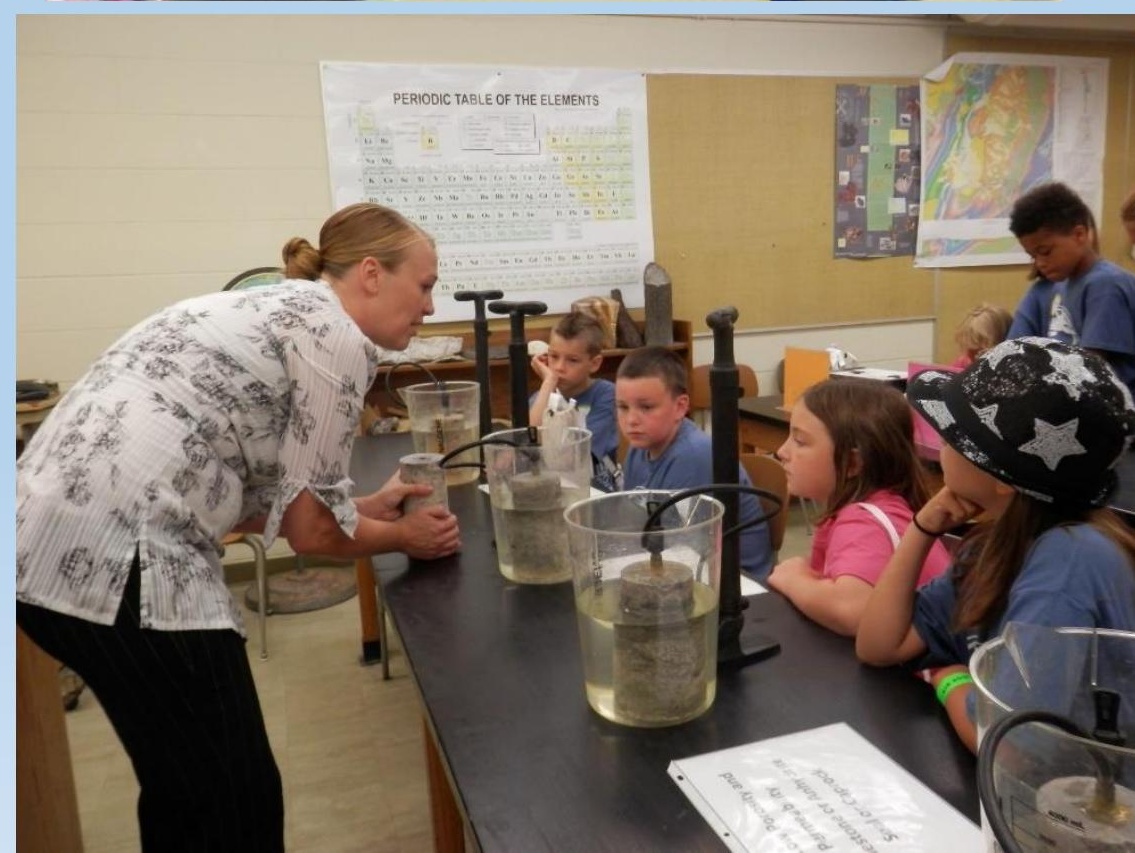




\section{Lessons Learned from 12 Years of \\ Community Outreach and Engagement}

- Build networks - CoreKids works with a variety of partners

- Financial support-donors

- Provide venues and joint event opportunities

- Communication with members (Teaching Associations) - identify new events/partners

- Engage with the community

- Student educators - become role models to children

- Future Geoscientists

- Spark interest in K-12 students - may pursue careers

- Valuable training for College students - public speaking, communicating science, working with children and the general public

- Engage with Teachers

- Broadens the impact of the program - teachers take home new ideas and activities to use with their own students

- Use your State's Science Standards - Allows Teachers to fit your visit or materials to their syllabus 


\section{Acknowledgements}

- Over the past 12 years, the CoreKids Program has benefited from a vast network of supporters. We thank our donors and sponsors, our partner organizations, our Michigan K-13 teachers, and the huge number of WMU Undergraduate and Graduate Students who volunteered at our events ( $\sim 50$ different students!).

- Special Thanks go to the following Student Educators who developed new modules, resources, and activities or volunteered at many events:

Jennifer Porter Niah Venable Jennifer Fugaban Ann Gilchrist Dawn Caldwell Zakk Waber

Steve Barone Tony Boxleiter 


\section{MSEUM \\ the sodence and culture museum at Michigan State University \\ $\left[\mathbf{A I R}{ }^{\circ} \mathbf{Z O O}^{\circ}\right]$, Like No Place}
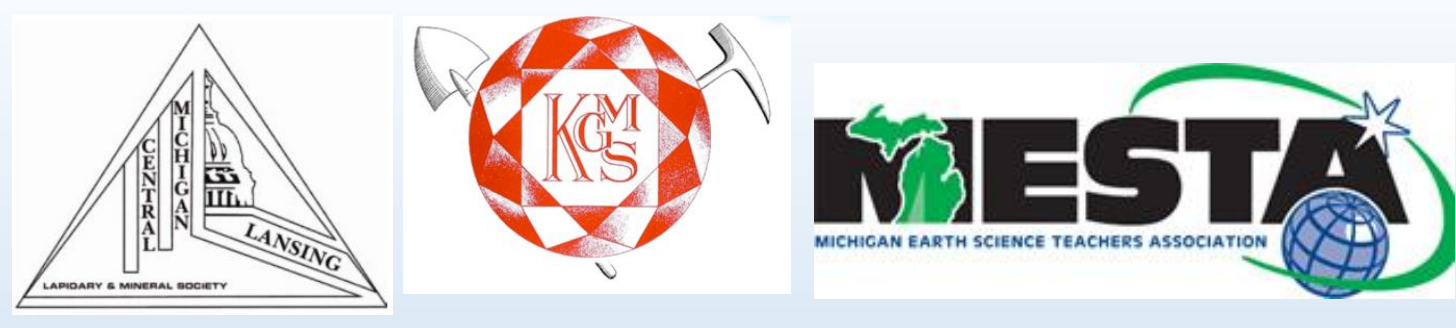

D $=2$ Department of Environmental Quality

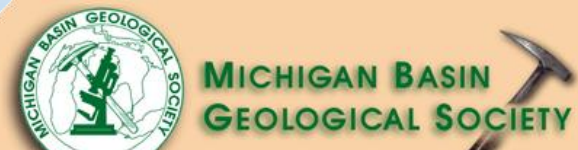
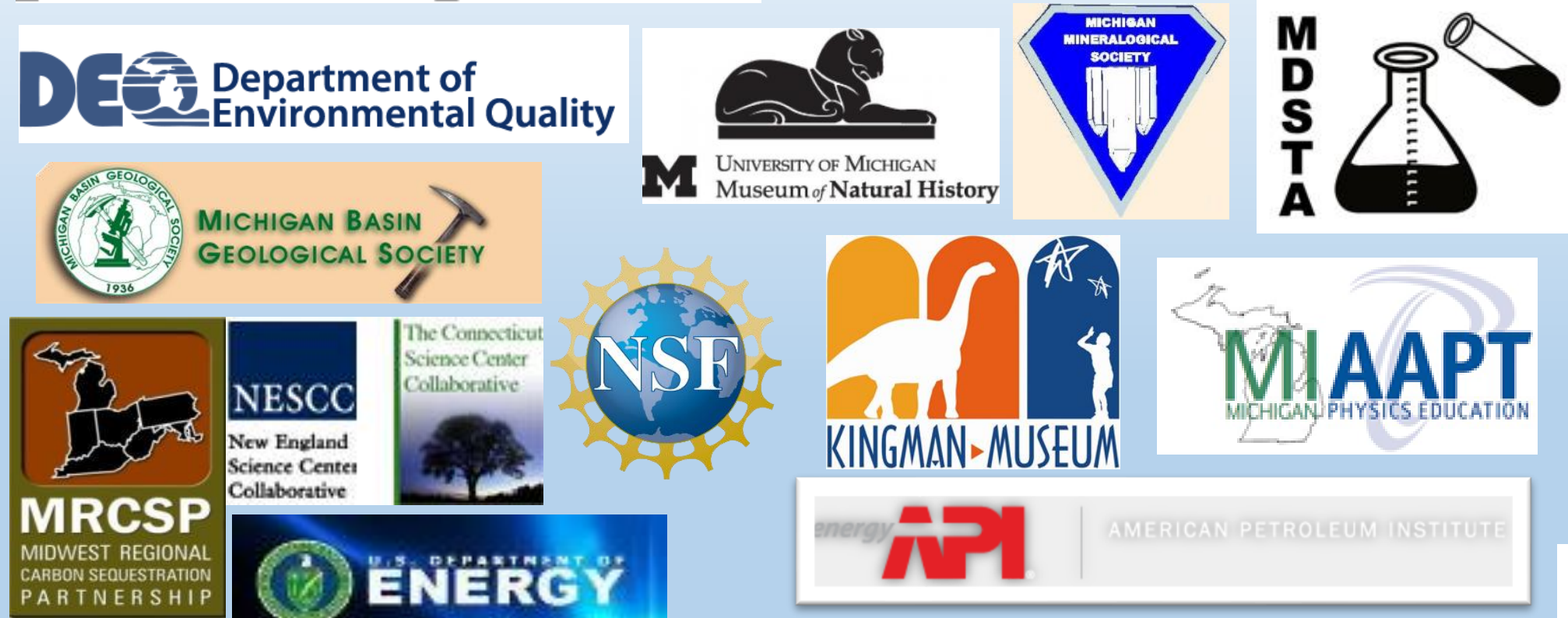
Collaborative

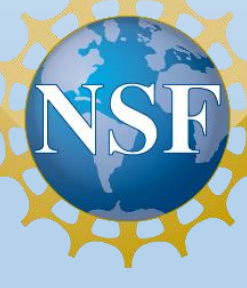

\section{ENEREY}

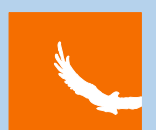

Keystone Science School
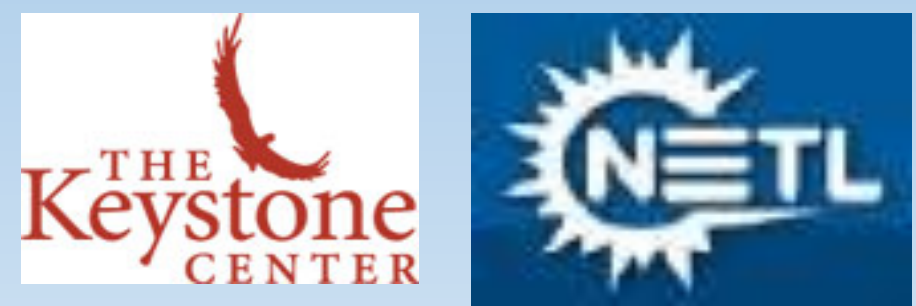
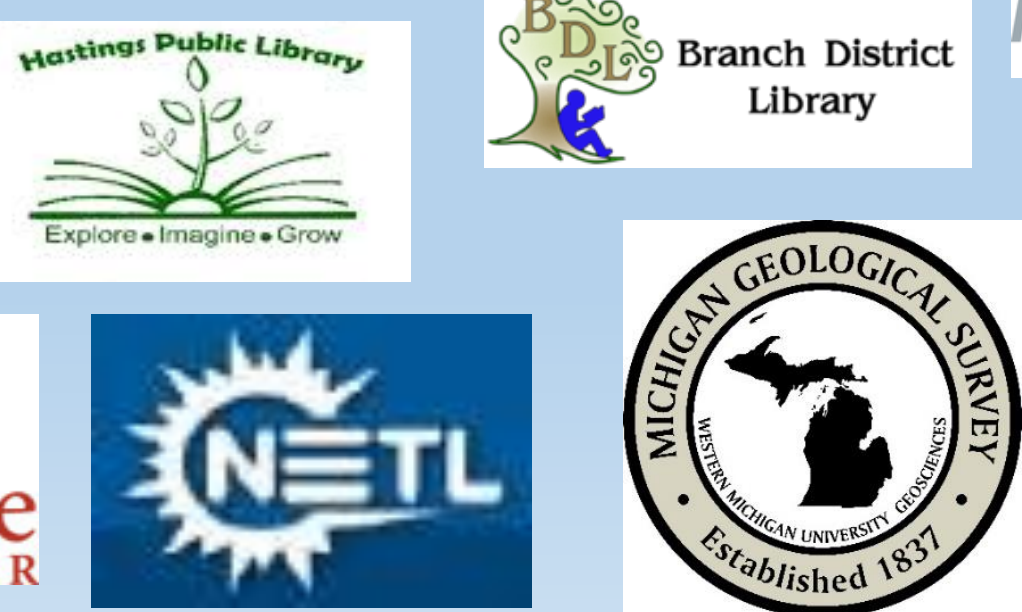

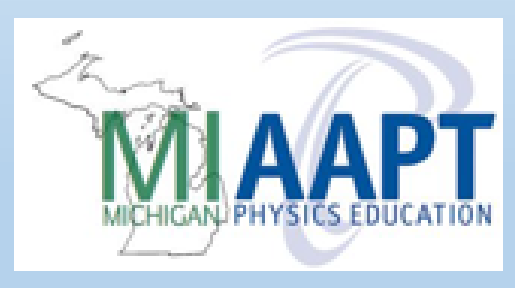

MiCareer Quest

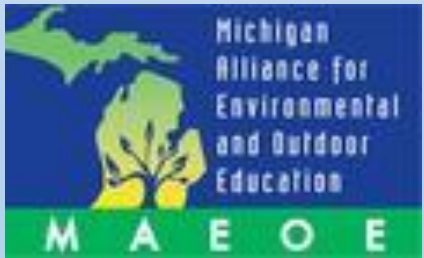

\section{DTE Energy \\ Foundation}

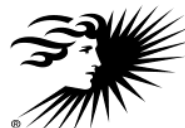

\section{Gonsumers Energy}

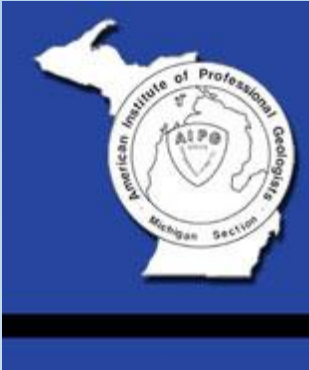

Count on Us

Department of Geosciences

MICHIGAN GEOLOGICAL REPOSTIORY

FOR RESEARCH AND EDUCATION

(MGRRE)

$(100)$ 